\title{
Symbolic Interactions in Popular Religion According to Dimensions of Religiosity: A Qualitative Study
}

\author{
Vlaho Kovačević ${ }^{1,+ \pm(\mathbb{D}, \text { Krunoslav Malenica }}{ }^{1, \ddagger(D)}$ and Goran Kardum ${ }^{2, *(D)}$ \\ 1 Department of Sociology, Faculty of Humanities and Social Sciences, University of Split, 21000 Split, Croatia; \\ vkovacevic@ffst.hr (V.K.); kmalenica@ffst.hr (K.M.) \\ 2 Department of Psychology, Faculty of Humanities and Social Sciences, University of Split, 21000 Split, Croatia \\ * Correspondence: gkardum@ffst.hr \\ + Current address: Poljička 35, 21000 Split, Croatia. \\ $\ddagger \quad$ These authors contributed equally to this work.
}

Citation: Kovačević, V.; Malenica, K.; Kardum, G. Symbolic Interactions in Popular Religion According to Dimensions of Religiosity: A Qualitative Study. Societies 2021, 11, 30. https://doi.org/10.3390/ soc 11020030

Academic Editor: Gregor Wolbring

Received: 11 January 2021

Accepted: 25 March 2021

Published: 31 March 2021

Publisher's Note: MDPI stays neutral with regard to jurisdictional claims in published maps and institutional affiliations.

Copyright: (C) 2021 by the authors. Licensee MDPI, Basel, Switzerland. This article is an open access article distributed under the terms and conditions of the Creative Commons Attribution (CC BY) license (https:/ / creativecommons.org/licenses/by/ $4.0 /)$.

\begin{abstract}
The purpose of this paper was to interpret the usage of symbols in popular religion based on contemporary symbolic interactionism using the reference framework of the symbolic community. The strength of the chosen symbolic interactionist approach is primarily in the research of the role of different dimensions of the religious in understanding the meaning of popular religion in the symbolic community. The qualitative approach and the method of in-depth semi-structured interviews were employed in the research, which responded to the main goal of the research on the meanings the participants of the popular religion attach to the symbolic interactions. A deliberate sample was used for the selection of participants in the popular forms of celebrating the days of Our Lady of Vrpolje, Our Lady of Sinj, and Our Lady of Karavaj as well as the Guardians of Christ's grave in Vodice, Croatia. According to the results, popular religion, transmitted through visible signs, places believers in a position of physical contact with the supernatural world within a symbolic environment. To achieve this, popular religion displays a need for sacred images, words, sounds, signs, movements, smells. Believers in popular religion seek to establish as simple, intimate, and direct relationship with a deity as possible. The respondents' answers confirm that the experiential dimension of religiosity is lived primarily on a personal level that precedes the social dimension. For the participants, the religious community has a symbolic character in terms of creating strong bonds between members of society or a social group, especially within the symbolic meaning of a feast day.
\end{abstract}

Keywords: symbolic interaction; community; popular religion; dimensions of religiosity

\section{Introduction}

Visual symbols [1] are a very important element of religions throughout the world. How do they affect the psychological and social functioning of an individual? Religious symbols have been explored in different theories including psychological [2] and sociological [3-9] perspectives.

A sign points to something we already know whereas a symbol points to something unknown, mysterious, and transcendent. The dual character of the real and the unreal is inherent in the symbol [2] (p. 168). In that context, symbols are very important to religion and spirituality. We will define the notion of signs and symbols and their fundamental features, and explain the relationship between the key concepts of the sign and the symbol in the context of religion. Signs that have a hidden meaning in the Greek language are called symbols [10] (p. 55) because their meaning cannot be reached by senses from their physical manifestations of nature [11] (pp. 114-115). The sign aspires for spirituality and thus approaches the symbol. All symbols are therefore signs, but not all signs are symbols. Smoke, for example, is a sign of fire, but it is not a symbol. The symbol is never natural, but always a cultural sign, i.e., a sign freely chosen. On the other hand, it is always chosen 
on the basis of the fact that its nature or its properties contain elements that represent a certain analogy (conclusion based on similarity) or correspondence with what is to be symbolized. The creation of a symbol is not a rational process, for a rational process could never produce an image that represents the content that is at bottom incomprehensible [2] (p. 161). A symbol represents something that is not wholly understandable and something we think intuitively about. An atheist will often view the cross as a sign that, when it appears on a wall, represents a particular type of a building like a church but for Christians with the lens of faith, the cross is symbolic and pointing to the transcendent and the mystery that is God.

The main framework of the theoretical approach of this research is the perspective of symbolic interaction [12], also called symbolic interactionism, relying on the symbolic meaning that people develop and upgrade in the process of social interaction. The term "symbolic interaction" was used by Herbert Blumer in 1937 [13]. "Symbolic interaction" refers to a particular feature, typical of human interactions, the ability of human beings to interpret or "define" mutual actions. People do not react "directly" in mutual actions, rather their reaction is based on the meanings they attach to such actions. "Blumer was among the first few sociologists who used group discussion and interview methods with key informants in their research" [14] (p. 8). The connection with the need of individuals for meaning (Max Weber) introduces us with Herbert Mead's perspective of symbolic interaction in American sociology in the 1920s [15]. It follows its roots as an interaction between individuals (Georg Simmel and George H. Mead).

Symbolic interaction is a theory in social sciences that based on symbols and symbolic interaction examines the meanings. The theoretical part of this paper focuses on social interactions and the meanings of popular religion in Croatia as well as on the role of symbols in the experience and life of the popular religion in Croatia through social interaction in the creation of a reference symbolic community [16]. From the above mentioned, we can see how signs and symbols reveal our own nature, which is symbolic and allows us to focus, to become more attentive to the reality that we reach through the symbol, the sign. As soon as the marked reality becomes visible, the sign becomes useless, since it is by its nature always the bridge that connects the two worlds, one of which is hidden by the other, and its meaning is revealed by the sensations of physical nature [17]. The world of symbolic signs is not opposed to the world of things-in-themselves, and does not receive purely immanent value and truth, but is directed towards someone Other and points to someone Other [18] (p. 37). Symbolic interactionism has a triple role in this work: psychological, sociological, and methodological role. Symbolic interactionism refers to a 'theoretical perspective' that sees 'human actions as constructing self, situation and society' [14]. Individuals construct their perceptions and meanings as a result of their interactions with others and individuals' interpretations influence their action in society.

Here, we take a perspective towards symbolic sociology and the system of signs and symbols in understanding the popular religion and religiosity of Croatian society as a historically living part of history and maintained social and spiritual continuity. A modern society marked by the scientific and technological revolution and mass culture first led to the alienation of individuals from religion and then to the return of the sacred as well as the return of some older, traditional forms of religiosity.

One of the traditional forms of religiosity is folk or popular devotion. It is in its simplest form an experience of the sacred, in which individuals participate in traditional feasts, old rituals, and pilgrimages [19]. The unity of the popular and the sacred brings unexpected fertility in deciphering the meaning of religion in general. In itself, it forms the originally religious in human and the scheme of establishment and organization of the sacred. Popular religion today, instead of diminishing as it has been demonstrated by many, grows and develops in unsuspected proportions [20] (p. 27). Today not only theologians, but many anthropologists, sociologists, psychologists and political scientists research it; it has entered deep under the skin of the modern man [21] (pp. 593-610). 
The characteristics of popular religion are referred to as corporeity, festivity, ritual, humanity, and seeking temporal graces [20] (p. 37). R. Plannet specifies popular religiosity with four features: tradition, emotion, morality, and hope [22] (p. 93). In a wider sense, it is defined as collective testimony, lived history, collective biography, a shared experience of the sacred and the miraculous [23] (p. 743). Rituality is an essential component of popular devotions, and where it is absent, there is no popular devotion, but perhaps a wider and much more general popular religion [23] (p. 746).

The inspiration for the study of the symbolic dimension in the popular religion originated from the need of turning sociological attention to the part of the social reality of popular feast days in Croatia as an integral part of popular religion. Symbolic interactions impose meaning on various types/reasons for the appearance of popular religion in popular feast days in Croatia. In this way, it is possible to get a more complete picture of popular religion, a place to agree on its fundamental meanings and the reasons for continual disputes over popular religion in Croatian society. This is primarily due to the lack of understanding of popular religion in the symbolic interactions in symbolic community, as well as the participants involved in the interaction.

In Croatian history, the Catholic Church played an important role in strengthening and preserving the national spirit. Over time, it became one of the most prominent symbols of national homogenization. Considering the importance of this historical factor, it is not surprising that the Catholic Church in Croatia has expanded its activities to popular Christianity in Croatian society. Precisely such a form of participation in religious life is a manifested expression of the symbolic domain mediated by the Church's social power [23] (p. 756). In Croatian society, this means that today's thinking about religiosity is directly related to the role of religion and the Church in the past as well as to the nature of social processes that have greatly influenced the social functions of religion.

Today, popular religion is most often observed in literature as a motive for seeking out the lost content of a true religious game rather than as an ideal place to find those contents in the symbolic community [24].

Through resolving these difficulties in the existing literature, we come to the basic theoretical assumptions that we rely on in constructing the methodological framework of our empirical research on the symbolic interaction in popular religion.

\subsection{Popular Religion as a Symbolic Community}

The need to belong is the most important meaning of the community [25]. This meaning of belonging, psychology tends to see primarily in human's basic and constant desire for the establishment of immediate, direct, and beneficial relationship with the world of the sacred in popular religion. Psychologists point out that in popular religion there comes the need for simplification of doctrinal strictness and theological accuracy, but also the craving for experiential living of religious content. In the center of that religion there is communication with the world of the sacred. Feelings prevail over the intellect, the mass of feast days over the loneliness. The causes for the emergence and spreading of popular religiosity should be first sought in the escalation of secular ideologies that have emptied the world from the sacred and provoked in human an unprecedented thirst for religion. That is why it is often sought using a shortcut or it transforms the secular in the sacred [26] (pp. 83-84).

In an attempt to express herself/himself through thoughts, feelings, words, and actions, human finds that for many inexpressible realities of life which seek explanation for the inexplicable, to simplify the complex, to put in certain forms that which by its nature has no boundaries, and cannot stand the patterns, symbols are required, as initiators, instigators, policymakers, and possible life supporters without which one cannot live as a human-the incarnation of the spirit [27] (pp. 33-34). Hence, the attempt to understand social action through the significance that participants attach to them in popular religion. In the analysis of the meaning, we give particular importance to the participants of popular religion in their everyday life and the way their life reflects on popular devotions. 
It is precisely here that the benefit of understanding popular religion as a symbolic community comes to the fore in which the members of popular religion generally conceptualize devotions with collective memories as the narratives of the past, and also include individual beliefs and the level of institutionally included social interaction [28] (p. 79). In so doing, participants understand the popular religion and devotions of Croatian society as a historically living part of history, the bridge between the past and the future, and social and spiritual continuity. These popular festivities as an integral part of popular religion become the social phenomenon and the secular institution of communion.

The community has a symbolic character in the sense of creating strong relationship between members of society or social groups in popular religion [29]. The community is based on the symbolic construction of borders within which, in relation to others, it may have different interpretations of the meaning of the communitas [29]. Anthony Cohen's community is not viewed as something that has a structure that can be objectively defined and described. Instead, he tries to understand the symbolic community "by seeking to capture members' experience of it" [29] (pp. 19-20).

"According to Victor Turner, community is best understood as communitas, a notion that highlights a particular kind of social relationship that exists in all kinds of society and which is not reducible to community in the sense of a fixed and spatially-specific grouping" [25] (p. 49). It signifies "giving recognition to an essential and generic human bond, without which there could be no society" [30] (p. 97). "Communitas breaks in through the interspaces of structure, in marginality; and from beneath structure, in inferiority. It is almost everywhere held to be sacred or "holy," possibly because it transgresses or dissolves the norms that govern the structured and institutionalized relationships and is accompanied by experience of unprecedented potency" [30] (p. 128).

Turner makes a sharp difference between communitas and primitive or archaic society, seeing communities as present in all types of society [30] (pp. 96-130). Communitas is supported by anti-structures, when the "structure" resists. Thus, it is always in opposition to the structure, towards the usual, everyday order of things in society. Turner paid special attention to one "extra" structural or "meta" structural modality of social interrelationship that he calls "communitas" [30] (p. XVI). This relationship occurs when the anti-structure comes into play.

Turner's argument about the community is that the community must be understood to the opposite structure. This is not something that is typical of pre-modern societies; it is neither anti-modern nor antithesis to society. For Turner, communitas has a cognitive and a symbolic role: liminalism, marginality, and structural inferiority are the conditions in which symbols, rituals, philosophical systems and artwork are predominant. For Turner, the community has a symbolic character in the sense of creating strong bonds between members of a society or social group. His theory emphasizes the binding nature of communitas.

In other words, anti-structure (re)generates structure; the "normal" lives (also) from the meta-or extra-normal" [31] (p. 39). "Society (societas) seems to be a process rather than a thing-a dialectical process with successive phases of structure and communitas. There would seem to be-if one can use such a controversial term-a human 'need' to participate in both modalities. Persons starving in one in their functional day-to-day activities seek it in ritual liminality. The structurally inferior aspire to symbolic structural superiority in ritual; the structurally superior aspire to symbolic communitas and undergo penance to achieve it" [30] (p. 203).

This means that the shape of a symbol can remain the same in the symbolic interactions in popular religion, but its content can change as society changes. Moreover, it suggests that popular religion for different members takes on different, and yet consistent, and so "common" meanings that must be based on uniformity. Cohen believes that "people can participate within 'the same' ritual yet find quite different meanings for it" [29] (p. 55). The meaning of symbolic reality is that it has no objective content or distinctive meaning. The form of the symbolic reality can persevere, but the meaning of the form may change. "This gives to symbolic forms a versatility that can allow them to adapt to the 
changed circumstances" [25] (p. 51) in the social context. The symbolic interaction in this paper is described at the level of symbolic structures common to all forms of sacral representation [32] (p. 9).

\subsection{Popular Religion within the Perspective of Symbolic Interaction}

Popular religion and its celebrations re-affirm the general meaning of social interaction for understanding the social movement, especially the one that emerges through the symbol, enabling the participants to actively create and recreate their world [33] (p. 62). The ability to create and respond to creation is linked to our belief, not just to what is the consequence of coercion of the social system. It is a current process where the participants are constantly responding to the creation with regard to the symbolic meaning they attach to the position of the one who initiated the action. Religion is an intersubjective act on the meanings attributed to objects and events, and they (the meanings) emerge from the process of interaction and are not present at the beginning, forming further procedures. "To some extent, the meaning is created, modified, developed, and changed within the interaction process" [34] (p. 519). Today, many participants of popular religion remain in Croatian society within the integrative function in the symbolic interaction in the same situation as before, this also having negative consequences on human life in the form of contemporary modern ideologies [24]. The reason for their similarity is that they observe the religion of the people exclusively through the optics of social conflicts, protests, disputes, class moments, etc. [35] (p. 123). This is true especially in modern society characterized by a scientific-technological revolution and mass culture [36] that has led to the alienation of individuals from religion, yet later to the return of the sacred and thus to some of the older, traditional forms of religiosity.

In terms of different areas and theoretical directions, it is possible to historically incorporate various types/reasons for the appearance of popular religion in the religious image of Croatia [23] (pp. 753-756). The first reason is a certain use of religion for purely political purposes and goals. The second refers to the remnants of pagan mythical consciousness, which has been preserved in the collective memory of peoples throughout centuries. The third reason hides in the aspirations of a modern human to seek the sacred in a world of complete secularization of personal and social life. The fourth reason lies in the conflicts within the Church itself, where official and popular religions are incompatible. The four reasons for the appearance of popular religion make a certain typological review of popular religiosity.

Popular religion celebrations in the perspective of symbolic interaction in Croatia enter the frame of the paths leading to the sacred, but they (festivities) insufficiently reach it in the social environment [37] and are similar to secular holidays [20] (p. 163). This shows how members of popular religion generally associate religiosity with the psychological and social dimension of belonging and imagination of social relations, failing to achieve stronger bonds in the symbolic community among members of popular religion.

This primarily derives from the neglect of the symbolic interactions of the sacred in the representation of sacral influences and their fundamental features in the symbolic community, which are always active in popular religion and devotions [38]. Hence, the lack of awareness of cognition and knowing of symbols as Christian; insufficient personal importance or personal identification with Christian symbols; insufficient commitment to the use of selected Christian symbols; and insufficient importance of selected Christian symbols for the symbolic Christian community. This disables the sacral symbolic understanding and determination in a symbolic Christian community [39]. Christian symbols are transformed into the ritual, the cult, the sign whose meanings become the first and most effective factor of integration in society [37] (p. 40). These meanings in Croatia improve unity, gathering and connection of community - family, gender, tribe, or people [23]. In fact, the integrative function of Christianity in Croatian territories, especially Catholic and Orthodox, has become far more prominent through ceremonies of rites and manifestations of symbols than through cognition and knowing of Christian doctrine [23]. 
In Croatian social memory, there is also present popular Catholicism, which was exhausted in mass ritual gatherings, numerous pilgrimages, celebrations of church feast days and national anniversaries, visiting popular religious festivals and sanctuaries, engaging in Marian devotions and celebrating national patrons days [23] (pp. 187-188). We start from symbolic interactionism, which views religion in social constructions through human interpretation, in which the participants of popular religion interpret each other's behavior or define mutual actions, and these interpretations form a social bond [13] (p. 2). Both in the past and today, not only Christian reasons (spiritual humility, religious conversion, Christian forgiveness, and goodness), but also political confrontations defined mutual actions [23] (p. 188); [40] (p. 296). These interpretations of reciprocal actions in popular religion are called "definition of the situation" on the basis of which "the people through religious rituals are aware of their past, but at the same time they are strengthened and homogenized in opposition to hostile ideology" [23] (p. 188). Hence, it is much more important to know what members of popular religion think that is happening in popular religion than "what actually happens" [41] (p. 4).

On the one hand, the reference framework of community feast days in popular religion demonstrates its dependence on a concrete structural social, psychological, cultural, and historical context and the circumstances in which an individual was born, educated, and in which she or he lives. On the other hand, within the reference framework of Victory Turner [30] and Anthony Cohen's identity symbolic community [29], it is possible to understand the community feast days and to analyze and research them more thoroughly within their appearing forms, anti-structural features, developmental dynamics, and potentials. The theme and problem complex of the reference framework of the community of popular religion was interpreted using in-depth semi-structured interviews, paying particular attention to the relationship (or to dialectics) of the symbolic structure of the community as a social and religious phenomenon [42]. The focus of our interpretation will be a series of diverse topics - religious experience, prayer, pilgrimage [19], understanding the sacred, roles, and meanings of symbols in the religious (Christian) context [16], popular religion and devotions, symbolic representation of the sacred and community. All of these topics will not exhaust the barely perceived conceptual and empirical universe of popular religion, but they will convincingly present great, strategically important potentials in a difficult yet urgent work of reaching the well-hidden weaknesses of individual and collective return to tradition and the "organic" unity of popular religion and society and religiously (non)aware behaviors.

The primary interest of this research is an approach to the collective interaction of the participants of the popular religion as a psychological and social phenomenon within symbolic interactionism, related with the influences of meaning and symbols on human action and interaction. We try to explore the meanings of symbolic interactions among the participants in the feast days.

\section{Methods}

The research is qualitatively, narratively based on the interpretative research paradigm according to the guidelines (instructions) for the application of qualitative methodologyStandards for Reporting Qualitative Research (SRQR) and Consolidated Criteria for Reporting Qualitative Research (COREQ) ([43] (pp. 349-357); [44] (pp. 1245-1251)). The research was conducted employing an in-depth interview approach at the beginning of 2018, based on a semi-structured protocol with 20 participants, and the protocol was approved by the Ethics Committee of Faculty of Humanities and Social Sciences, University of Split (Class: 003-08/21-03/0002 Ref.No.: 2181-190-02-7/2-21-0001).

The key criterion for selecting participants was participation in the rites of popular religion. The research participants were given the opportunity to withdraw at any time, which was not the case. The conversations were recorded and later thoroughly transcribed. During the process, the interviewer made his own notes and observations to facilitate the coding, analysis, and interpretation the data. Two researchers, an interviewer-student 
and a mentor were engaged in the coding process. In line with the initial assumptions, the research object within symbolic interaction is their relationship in interaction with Croatian popular religion. We have limited ourselves to the analysis of the symbolic interaction within one segment of believers belonging to the Catholic Church ("Guardians of Christ's grave", "Our Lady of Vrpolje", "Our Lady of Sinj”, and "Our Lady of Karavaj”). In accordance with the research topic, the basic objective of the research is to: examine the special experiences, events, states (of consciousness) of the participants or actors in a certain interactional context of symbolic intractability as a symbolic community. The best way to elaborate the underlying postulate in detail is within an operating model [45] (p. 203).

In the research of the symbolic interaction of the sacred in Croatian popular religion as a symbolic community, we focused on certain selected dimensions of religiosity of the participants of folk festivities, which rely on verified opinion [46]. The authors modified the five-dimensional scale founded by Charles Y. Glock. Glock's (1962) [47]. The multidimensional conceptualization of religiosity presupposes the existence of five dimensions: (1) ideological, (2) ritualistic, (3) experiential, (4) intellectual, and (5) consequent. De Jong Faulkner and Warland borrowed the basic analytical data process and found support for a multidimensional hypothesis. They found seven factors for American students and six for West German. The conceptual domain, represented by the factors, contained: (1) believing, (2) experience, (3) practical religiousness, (4) knowledge, (5) social consequences, and (6) individual moral consequences. For American subjects, religious knowledge has formed two factors in relation to biblical and non-biblical religious figures, ending up with four factors for the American pattern.

Symbolic interactions of participants have been researched by a protocol consisting of six categories and the related topics of conversation that served us as a framework of interpretation and understanding of the research phenomenon. The structuring of the interview was done for two reasons: because of the very nature of the paper, i.e., the aims and the object of the study, and because of the extremely abstract and complex theme. The participants were offered a certain conceptual framework within which it was easier for them to think about complex occurrences and verbalize their attitudes and opinions while at the same time providing them with the freedom to express their understanding and interpretation without limiting the pre-set answers. Questions were formulated for the purpose of this paper, because of the above-mentioned specifics of the subject matter. Our research has taken on a "six-dimensional" research, which mentions intellectuality, ideology, ritual, experience, and individual and social consequences as important dimensions or factors which can determine the structure of religiosity. This structure of religiosity, we believe, is important because of its relevance in social integration-as the totality of the religious experience of an individual, a community, or a period. Consequently, it also makes the constituent elements of popular religion as a symbolic community within the practical position among the members of "Guardians of Christ's grave", so-called "žudije", popular feast days of "Our Lady of Vrpolje", "Our Lady of Sinj", and "Our Lady of Karavaj" within their own sociocultural values.

Research questions are discussed below, indicating a need for further research and using other research approaches and methods. This will be of particular benefit to the evaluation of variables about which the participants in the pilot phase were indecisive.

\section{Interpretation and Discussion}

Relying on symbolic interactionism, in this section we will attempt to systematize the basic principles of this theory and interpret the results within a multidimensional conceptualization of religiosity. It is difficult to describe contemporary symbolic interactionism because this approach in sociological theory has a deliberately embedded ambiguity and is resistant to systematization [48] (pp. 18, 19). Namely, according to symbolic interactionism, in popular religion people are able to change or modify the meaning or symbols they use in action and interaction on the basis of their own interpretation of the situation [49] (p. 189). For example, the sacred is manifested in a variety of features through the medium of 
symbols: as supremacy, sensuality and subjectivity. Thus, the approach to the sacred in popular religion stems from human's everyday thought and spiritual situation, which is not viewed as independent but in symbolic interaction. Popular festivity is a space of meaning and symbolic interaction-situated in participants' words—and it has become part of the popular religion within the aforementioned main processes researched by modern symbolic interactionists.

Reporting the experiences of the participants, we touched on the popular festivity as a metaphorical movement between popular symbols and the sacred, bringing unexpected fruitfulness in figuring out the meaning of folk religion. Popular religion thus linked the participants of the popular festivity to the original mystical reality that precedes all subsequent institutional and ecclesiastical framings; it is a sacral primum, the sacred that is imperfectly revealed to the people from the womb of memory beginnings. The sacred is a permanent primal and original experience of the transcendent and the extraordinary, and religion is merely a translation of that personal experience into the language of a particular culture. The sacred would be a yet non-institutionalized religion, and religion would be the institutionalized sacred. In modern religiology, it can be reduced not only to the religious and religion, but also assumes designations of the secular, especially the media and above all the political [40] (p. 5).

Popular religion, from a sociological perspective, never acts on its own. It is conditioned by the process of social interaction; participants in popular religion symbolically convey meanings to other participants involved in the action. Other participants interpret these symbols and direct their responses based on their interpretation. In other words, in social interaction, the participants in popular religion engage in a process of mutual influence [49] (p. 192), whereupon the anthropological approach to this social interaction focuses solely on the emergence of popular religion and the category of the popular, national, subordinate, simpler. The sociological approach emphasizes also the other side of this phenomenon in the form of the official church religion and the use of terms related to supremacy, ecclesiality, authority, power, and hegemony [20] (p. 18).

In popular religion, "social structure consists, rather, in everyday practical routines; practices that embrace, in their contextual and embedded character, the accounts people give themselves and each other of just those practices" [50] (p. 97). This is where the degree of belonging to a symbolic community comes from, experienced within the community and tradition. "In short, recognizable sense, or fact, or methodic character, or impersonality, or objectivity of accounts are not independent of the socially organized occasions of their

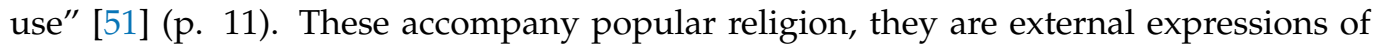
faith that are not necessary as such, but are useful if their foundation is not forgotten. "Common-sense understanding of everyday activities is constitutive as well as explanatory of these practices" [50] (p. 97).

Mutual affiliation is based on the source of that affiliation and it is not of great importance whether it is manifested or not manifested the explanation which gives 'rationality' and comprehensibility to the complex moral order that implicitly organizes mentioned activities. "Schutz and Garfinkel explicitly highlight the 'natural attitude' as the institutional, interactive structure of society; and seek to explicate in different contexts and with differing levels of generality how this structure emerges and operates, how it is renewed and persists" [50] (p. 97).

Namely, Harold Garfinkel uses "the term 'Ethnomethodology' to refer to the investigation of the rational properties of indexical expressions and other practical actions as contingent ongoing accomplishments of organized artful practices of everyday life" [51] (p. 11). Garfinkel points out that common-sense understanding of everyday activities is constitutive as well as explanatory of these practices:

When we talk about "common sense knowledge of the facts of social life for the members of the society, we talk about the institutionalized knowledge of the real world. Not only does common sense knowledge portray a real society for members, but in the 
manner of a self-fulfilling prophecy the features of the real society are produced by persons' motivated compliance with these background expectancies" [51] (p. 53).

Pace [52] claims that in Croatia religion developed the main features of the national culture shaped by the European historical, cultural, and political matrix within which it occurred. Croatia is part of Western culture which can be seen in the events and motivations that present the clearest reflection of the cultural identity of the nation [53]. In Croatian society, religion manifested in its first type as a means of social integration of the people in its efforts to preserve and keep its national identity in the face of threats from the political (or atheistic) enemy. Other types or reasons for the emergence of religion played a negligible role in the religion of Croatian society [23] (p. 756). For Croats, religion became a means of struggle, and grew into a means of constructing, or more precisely preserving and reconstructing the national identity of the people themselves.

Along with such an understanding of religion goes the claim that religion acts as a politics of identity. Enzo Pace uses this term in his book Why Do Religions Go to War? [52].

The danger of understanding symbolic interaction in popular religion as identity politics due to the direction of the developmental processes of transformation and continuity of popular religion should be seen within Croatian society, discussing every type of "exclusive" or "ultimate" discourse, from social and historical to traditional and political, as the areas where living "authentic Christian life" is being lost. Hence, the understanding of Christianity in itself (the understanding of Christianity as a metasocial phenomenon that cannot be reduced or explained only by social relations, but which has its own social dimensions and functions). This approach attempts to answer fundamental questions about the origin, meaning, and function of Christianity (directly related to the philosophy and psychology of religion) within the context of symbolic interaction in popular religion.

Furthermore, Simmel argues that we need to preserve an awareness of relative independence from spiritual culture, i.e., the impossibility of sociologically reducing spirit and culture to social conditions without any residue. The human spirit is an instance that produces forms that faithfully exist independently of its creator and the historical and social moment of creation because their subject/creator is limited in time, the created being eternal [54]. According to Simmel, we can state that the symbolic interaction in the popular religion in the Croatian Christian context is directed towards objective products of culture, based on constant spiritual creation and the created based on the "formative instinct" of the spirit. This interdependence and connection contain the metaphysical meaning of Christianity as a historical product, without anticipating certain negativities of the historical spirit of Christianity; parareligious and pseudoreligious phenomena and, on the other hand, a false belief in the universal validation of some random, ephemeral forms.

In social reality, the popular within the symbolic interaction does not exist in itself, and therefore should not be either glorified or underestimated. On the other hand, the dominant within the identity politics in society does not exist in itself within symbolic interaction. Consequently, sociology should equally study both sides and their dialectical relationship, because the popular is regularly a result of the ruling ecclesiastical but also of the opposite, the popular [20] (p. 18).

In addition to its social, political, psychological security, symbolic interaction in popular religion, according to the dimensions of religiosity, is also a way of placing oneself in relation to the basic reality-the manifestation of something that emerges in the senses-in imagination, gesture, feeling. A symbol is also an expression of the foundation of a symbolic community that can be said to be shown and concealed. Yet, showing-hiding double meaning is not always concealing what is meant, rather it is sometimes "a manifestation, a revelation of the sacred." The phenomenology of the sacral in the consideration of interpretation and understanding should be understood as a preparation for the discovery of meaning.

Although popular religion was born among the "most alienated", popular religiosity belongs not only to the lower classes of society, as some claim [55] (pp. 85-116), but extends to the entire human community [20] (p. 69), whereupon it is not important if popular 
religion is partly formed outside the Church, in sacred folklore and magic [56] (pp. 941-953) or it is always situated within the broad confines of its constitution [57] (p. 11) of the phenomenology of the sacred since every phenomenology of religion is at the same time the phenomenology of the sacred.

The course of interpretation of the research results is delineated within the main processes that contemporary symbolic interactionists research, namely, the ability to think, opinion and interaction, learning meanings and symbols, action and interaction, selection, and the concept of a person [49] (p. 189). The participants' responses are placed within four analytical frameworks:

1. comprehension/interpretation and conception/perception of the sacred and the transcendent;

2. roles and meanings of symbols in the religious context;

3. popular religion, religious experience, and symbolic representation of the experience (of the sacred);

4. consequential dimensions of popular religion/religiosity.

Four analytical frameworks are derived from the defined multidimensional conceptualization of religiosity so that the first includes answers to questions about the intellectual dimension of religiosity, the second ideological, while the third combines the ritual and the experiential, and the fourth relates to the consequential-individual and collective-aspects of religiosity.

\subsection{Comprehension/Interpretation and Conception/Perception of the Sacred and the Transcendent}

Human beings' ability to think in order to reflexively act is embedded in human consciousness and is linked to socialization, meanings, symbols, person, interactions, and even society. We have operationalized this process of understanding/interpretation and conception/perception of the sacred and the transcendent in popular religion by asking questions about God, belief/faith, religiosity, the sacred. The answers indicate that the respondents have consciousness to the end of the unreachable, mysterious and enigmatic origin and Eschaton, the world, life, and death that precede the objective part [58] (p. 76).

Respondents' answers show that one cannot speak unequivocally about God, much less in His Name-it is often better to be silent about Him.

"In my opinion, God is indescribable love, mercy above all, and therefore difficult for us to understand." (S9)

"I agree with the conclusion that it is easier to define what God is not rather than what He is. To me personally, God means something that is only stable today in everything we do and live... God is comfort, help, peace, joy." (S12) "... despite all the suggestions of not imagining him as a character, he (God) is still for me a man with a beard who watches over me and directs me in life. God is the guiding thread." (S13)

"... it is hard to imagine sometimes what a person in the spirit feels, but certainly God is the father. I know that He loves me till the end, unconditionally, but that is right on an experiential level... it is not something I think, but what I experience and feel. So the absolute love, but He is also a person. I have a personal relationship with God, not something imaginary but personal." (S14)

"... the sacred, spatially viewed, can be related to temples, consecrated places; in terms of time, it may be an isolated time of prayer, liturgy; and existentially, it can be an encounter with what is truly important-with people, with their fragility, especially where people are open, where there is suffering, I think there lies the sacred. God is present where people need human closeness..." (S2)

"the sacred is that which is mysterious, hidden; something that transcends human, something to which/to whom man is related. The sacred cannot be without relationship... it is actually a prefix given to God. God is sacred..." (S3) 
"For me, God and the sacred are an experience of intimacy, separation in a way, but on the other hand a complete presence, a dimension of love and togetherness, intimacy. It is God who has come to us and is being given to us." (S8)

According to the sociologist and anthropologist David I. Kertzer [4] (p. 11), three basic features of the symbolic interaction of the sacred can be distinguished on the basis of the participants' responses: condensation of meaning, multivocality or ambiguity, and ambiguity or indeterminacy of meaning. The condensation of meaning of the symbolic interaction of the sacred allows us to express ideas and emotions that are sometimes difficult or even impossible to express [59].

"While condensation refers to the interaction of different meanings and their synthesis into a new meaning for a particular individual, multivocality presupposes a different ability, the fact that different people can understand the same symbol in different ways" [4] (p. 11); [60]. All types of interaction, not just interaction during socialization in popular religion, perfect our thinking capacity.

Believer, by virtue of her/his ability to convert signs into symbols, as in Kant's criterion of 'indirect meaning' and 'analogy', brings symbol in close connection with metaphor. According to Kant, in humans, the symbol is an indirect representation of a concept (image) based on the study of such an analogy between two objects, which lies not in material similarity but in the rule of reflection, not in content, but in the form of reflection on those objects.

"The Judgement exercises a double function; first applying the concept to the object of a sensible intuition, and then applying the mere rule of the reflection made upon that intuition to a quite different object of which the first is only the symbol. Thus a monarchical state is represented by a living body, if it is governed by national laws, and by a mere machine (like a hand-mill) if governed by an individual absolute will; but in both cases only symbolically. For between a despotic state and a hand-mill there is, to be sure, no similarity; but there is a similarity in the rules according to which we reflect upon these two things and their causality" [61].

Kant considers the schematic and symbolic mode of presentation to be exemplary modes, which he contrasts with the discursive mode. "The intuitive in cognition must be opposed to the discursive (not to the symbolical). The former is either schematical, by demonstration; or symbolical as a representation in accordance with a mere analogy".

He emphasizes that these are modes of hypotyposis, that is, "'exhibitiones' ('Frege refers to it as 'Vorstellung' —an inner image that is created through memory and active experience'), and not mere characterizations." According to Kant, characterizations are "designations of concepts by accompanying sensible signs which contain nothing belonging to the intuition of the Object, and only serve as a means for reproducing the concepts, according to the law of association of the Imagination, and consequently in a subjective point of view".

"...for me, God is always alive... My image of God comes down to a personal relationship. That personal relationship is built communicatively, therefore, the relationship is alive, there is internal communication, internal conversation, there is listening, there is oblivion..."(S2).

This general ability to create concepts within thought and interaction can and must be shaped and refined in symbolic interactionism during the process of social interaction. Thus we come to the next significant process within symbolic interactionism for folk religion. The process by which we approach God in relation to a symbol.

Respondents show that communication with God requires breaking through one's own thoughts and feelings, entering into dialogue with those similar and different from us, and not taking anything for granted, especially not ready-made answers from anyone who offers them. They can only be given by God, and we can only taste, listen and hear them, over and over again, every day, in concrete situations of our lives rather than in abstract principles and regulations. 
Thus, the respondents confirm that the cognition of the world is the penetration of the sacred into the profane. The sacred has the character of being, existence, a kind of "fullness", and the profane has the character of non-being, non-existence and "emptiness"; in-between, as respondents show, there are countless transitions. On the one hand, the sacred is related to its original meaning, literally, sensory; on the other hand, the literal meaning is bound by the symbolic meaning that rests on it.

Therefore, the symbolic interaction of the sacred thus within the "complexity and uncertainty of meaning" that conveys, that is, multivocality and impartiality, is "the source of their power" [4] (p. 11), as will be shown on a concrete example of the role and meaning of symbols in a (popular) religious context.

\subsection{The Roles and Meanings of Symbols in the (Popular) Religious Context}

Respondents' answers indicate that religiosity plays a symbolic role in addition to the cognitive: liminality, marginality, and structural inferiority are conditions in which symbols, rituals, philosophical systems, and works of art are predominant. For the participants, the religious community has a symbolic character in terms of creating strong bonds between members of society or a social group, especially within the symbolic meaning of a feast day. The form of symbolic interaction in popular religion may remain the same, but their content changes, thus popular religion is not a rigid structure, but a "fluid" and vibrant formation, in constant change [31] (p. 40). A believer in popular religion seeks to establish as simple, intimate, and direct relationship with a deity as possible. Here, feelings over reason prevail, spontaneity over imposed, symbolic over dogmatic [58] (p. 42). We asked the participants about the definition and ways of constructing religious (popular) symbols, their religious meaning and role, ways of functioning and working, etc.

\subsubsection{Definition of Symbols and the Symbolic}

"... symbols are a union of the material, the visible, the tangible, the sensual, and something beyond that... symbolism goes from the elemental human life and contact with matter and other people, not only with matter but with the human in interpersonal relationships, rising, through society, to the transcendent."(S2)

"symbolic speech is one of the preferred speeches of religion and faith. This is the way faith is expressed... there are the sacraments and Christ Himself who is the symbol." (S8)

"(symbols) can have different meanings. The content of this symbolism is hidden, or you may interpret it differently. People participate in the same rituals and experience it differently. There is nothing that is absolutely bad on earth, nor absolutely good..." (S9)

\subsubsection{The Role and Meaning of Religious Symbols}

"... certain symbols, songs, they play a very important role. They are actually more important in the community than in the individual, at least it seems to me." (S4)

"... symbols are always a certain reminder ... they remind us, the symbols serve to remind us of what matters, and now the symbol is a cross, it is a symbol, but to go to mass and participate in the Eucharist is not a symbol, it is the reality of Christian life." (S4)

"I think it is important for every person to be able to compare with something that he has experienced, using some of his senses, to identify something that he cannot experience in such a way and thus try to better describe this kind of presence of something that is not exactly visible to those senses. I do not know, the sign of the cross is, I believe, a very good reminder of this very symbol of the cross... of Jesus on the cross, who in that step defines the whole meaning of our faith." (S10)

"Well, I certainly think that symbols always carry with them a message and have a deeper meaning. So the same is true with symbolism specifically in Christianity. When I make a sign of the cross, it may look like an exercise to someone, but it's not an exercise. I know that I put the name of God on myself, and already then I enter into a relationship with God." (S14) 


\subsubsection{Ways the Symbols Work and Function}

“... it is important to observe how certain symbols gain some social coexistence, strength and force, and how then some emerge from the social as religious symbols and connect, not only the individual but the whole community, the whole church with the transcendent. Experiences at the human level of relationship with God are condensed into language and symbols, so that in some way either experience which occurred, or the repetition of that experience, or the present relationship with God is symbolically brought to presence." (S2)

"I'm glad to have a rosary on my rearview mirror, it's mostly considered a charm, but it's a symbol... I feel calmer when I pass by the church and... let's say when I have the chance... let's say if I'm in Sinj, I often like to go to the church to calm down, to think about some things." (S5)

"... symbols do not function primarily as what is understood, understanding comes later ... symbols function on an emotional level, on a social level, on a level of trust and faith... a symbol when it becomes a real symbol, it has certain weight and strength which we cannot measure only rationally, they have some, let's just say, their dynamics, the variability of meaning and action, so then this is only one part in understanding the symbol ... So this symbolism has certain dynamic very dependent on my existential state." (S2)

Learning meanings and symbols in social interaction is a significant process of understanding popular religion for symbolic interactionists. Here, meaning does not originate from mental processes, but from a process of interaction in which it is necessary to distinguish between signs that are based solely on a convention where there is no resemblance. This relation is generally arbitrary and conventional (for example, for symbols representing a certain analogy between the signifier and the signified). Kant sees examples of symbolic depiction in the words of metaphorical origin, and in each of our cognitions of God, in every sensory representation of the beyond-sensory.

In this way, reality itself contains spiritual content that, in itself, directs through everything sensory in interaction. Human is no longer only in the physical universe, she/he lives in the symbolic universe. In Cassirer's Philosophy of Symbolic Forms, symbolic activity is the assumption or condition of the cognitionality of the world: "A symbol is not simply an accidental clothing of thought, but it is a necessary and essential organ" [62] (p. 366). Humans cannot face reality directly, but through symbols [63].

According to [33], symbols are important because they allow humans to act in a distinctively human way by actively creating and recreating the world we live in. He lists some of the specific functions of symbols for participants [49] (p. 191). Symbols thus enable people to connect with the material and social world, enhance the human ability to understand the environment and the ability to think, increase the ability to solve various problems, allow participants to transcend time, space, and even their own personalities, allow them to imagine even metaphysical reality, and the ability to avoid exposure to their environment [49]. Using symbols, participants can imagine what it would be like to live in the past or in the future. In addition, participants can symbolically transcend their own personality, fantasizing about how the world looks from someone else's perspective. It is a well-known concept of symbolic interactionists-assuming the role of the other ([49] (p. 192); [64]). Generally speaking, symbols allow people to be active rather than passive and to control themselves in what they do.

According to the founder of symbolic interactionism Herbert Mead, human thought, experience, and behavior are essentially social, through the fact that humans interact with symbols, the most important of which are contained in language. Symbols in popular religion take on a religious character, in social interaction "they always mean the transformation of the world into ontologically realistic structures and forms" [65]. Complying with the requirements of the received symbol message does not exhaust the effective reality of the symbol. In symbolic interaction in the encounter with the meaning of a symbol, we encounter not only its meaning and its action, but also ourselves (through the concept 
of a person). With the help of symbols, I can encounter another person and unite their freedom with mine in love.

In order to understand this concept beyond Mead's initial explanation, we must first understand the idea of self-observation (I in the mirror) developed by Charles Horton Cooley [49] (p, 193). By this he meant our ability to see ourselves the way we see any other social object. This idea can be broken down into three basic parts, which include imagining what we look like to others and what their judgment about us might be, along with developing a certain sense of self as a result of our ideas about others' judgments about us [49] (p. 193).

\subsection{Popular Religion, Religious Experience, and Symbolic Representation of Experience (Of the Sacred)}

The participants discussed popular rituals and other forms of popular religious practice: customs, feast days, and the living of the ethical values of popular religion. Participants confirm that popular religion is the answer within the anomie-induced deregulation of today's Christian community. Within it, the world was disenchanted, not only in a poetic sense, beyond the rigid boundaries of the confessional socialization of believers within the official church, but, as Jakov Jukić points out, it became "a desert that gives birth to a desert". The popular religion is here understood as an open system taking on different, yet coherent and, in so far, "common" meanings for different members. In so doing, members of popular religion as a community can enable the (apparently impossible) reconciliation of "communion" and individuality: people can participate in the 'same' ritual and yet find a completely different meaning in their [29] (p. 55).

"Popular religion is a rhythm that is not enlightened, not deepened, but has some good side and value ... existential problems and questions affect a person regardless of how he lives and they can occur in the most banal popular devotion." (S2) "It is in my view a form of how a people expresses their faith and devotion to God..." (S3)

“...when people's devotion is mentioned, this is thought to be rather reckless, unenlightened, it is inarticulate, it cannot be described, it is more or less a devotion that has not gone through personal filters, where no personal relationship with God occurred, and the like.... On the other hand, it is the most common and widest resource from which personal religiosity is born. There are very few people who come into relationship with God without any contact with popular devotion." (S2)

"It is important for our people that the priest can sing, if he can, that it is not good. The liturgy does not matter if there is no singing. They will come to Mass, but it does not touch them. The role of priests is to help their people understand the meaning of what they do. On the islands, people are very jealous of their tradition, but they do not know why they live it because it is not touched, it is important that they make a feast. It takes dialogue and meeting, and the motivation itself. I do not understand some of the things I do in the rites, so I try to understand, determine what is good to do and what is not. As our old men used to say, child always seeks an answer." (S8)

In understanding popular religion, selection is very important for interactionists. The conscious life of a human being is therefore a continuous stream of self-indications. The significance of indication as self-indication, according to Mead, lies in two senses. The first is to indicate that something is drawn from the totality of its environment as something special, that is, as a thing. The thing is a product of the ability of the individual to act, not some previous stimulus that has yet to cause the act. Another sense of the meaning of the indication is that the human being does not respond to the environment by self-indication as something that is simply "mentally given", but rather responds to a certain environment that is mediated through symbols, which is therefore the symbolic environment [66] (p. 326). It is only through symbolization that the sense of unity and the coherence of sensory experiences - that are otherwise chaotic and devoid of form-are reached and established. The imposition of a form to chaos is evident in all symbolic forms, in the language we speak, in the stereotypes we use, in the forms of art that we find attractive [41] (p. 4). Popular religion, transmitted through visible signs, places believers in a 
position of physical contact with the supernatural world within a symbolic environment. To achieve this, popular religion requires sacred images, words, sounds, signs, movements, smells. The saints who mediate between human's misery and the majesty of God play a special role [20] (p. 67). The term popular religion is reminiscent of supernatural beings, of holy places, of magical traditions, of miracle workers, of death-induced change, of religious practices at the local level, the creation and celebration of rituals and traditions, the blessing of people and harvest, brotherhoods and processions, sacred images, candles and medallions, crosses and calvaries [67] (p. 45). Respondents' answers confirm that the experiential dimension of religiosity is lived primarily on a personal level that precedes the social dimension, in the invisible dimension that precedes the external dimension. Similarly, through a religious act within the system of symbols that precede an active act, an individual morality that precedes political practice.

Prayer and Personal Relationship with God

"My image of God is not some static image that imagines a work of art in which I would see certain elements and interpret them. It comes down to my personal relationship. This personal relationship is built communicatively, therefore, from the relation to the Word, to the revealed Word. (...) That word and revelation to me is, at this point, extremely personal and that is where the relationship starts to be built. (...) So the relationship is alive, there is internal communication, there is internal conversation, there is listening, there is oblivion..." (S2)

"true prayer comes in silence and silence is very difficult ... The silence make you think about yourself and we all today try to think of everything other than ourselves. Therefore, a prayer means standing before God and absorbing mercy... Prayer is taking time for God." (S3)

"prayer is when one really wants to find some spiritual peace ... something that I understand on a higher level than thinking in my mind about I don't know what..." (S1)

"... I place it in the realm of language, in the realm of communication... to me, the notion of prayer appears primarily as attention, to God's nearness, to his will. So, I would simply define prayer as attention to the presence of God... that means to give some time and attention to his nearness." (S2)

"... unfortunately I am not someone who regularly prays and let's say that while I regularly prayed the rosary in a certain period, I felt better and did so during some family crises. And it gives me peace and I remember that there is a higher good and higher goals and eternal life and it gives me certain assurance of daily life. In relation to my parents, in relation to my brother, in relation to my girlfriend, to my employer, in relation to injustices that sometimes happen to me." (S5)

"Honestly, I do not know how I could live a day without prayer, because in prayer I am first in direct relationship with God, second I have the experience of prayer. I know when I pray that it is not without sense, therefore I know when I pray that God hears my prayers and that he answers them, and when a person has such an experience, then he cannot not to pray in a way." (S15)

The connection between popular religion within an objective social context and its influence on a religious phenomenon, as well as subjective interpretation of a religious phenomenon and its influence on society, develops religious interactions, rituals, and institutions, and they unite persons and social context. In general, popular religion has historically played a decisive role, as it provides mutual connection and social interactions within a particular area of the community through rituals, and they, as social arrangements, achieve the desired goals. Certainly one of the important social goals of popular religion is the role of a source of legitimacy for the religious community that no other system could give it. It is the task of the religious factor to provide the person with high social integration in which he or she will be able to truly accomplish themselves to the fulfillment of their personality and, accordingly, to express their personal growth in their effective shared connection within symbolic interaction [68]. 


\subsection{The Consequential Dimensions of Popular Religion/Religiosity: Identity and Community}

The impact of the (religious) experience of the sacred on everyday life was discussed with the participants. The participants suggest that with modernity, the religious community, as a tradition, inevitably falls apart in the face of the powerful and unstoppable bursts of modernization. The main tool for the disintegration of the religious community as a tradition is the total rationalization of all social life. Hence, the attempt to re-establish the religious community in certain traditional associations within the religious experience. In the presentation of social community, participants emphasize its symbolic nature. The community has a symbolic character in terms of creating strong bonds between members of society or a social group. The influence of the social community, the participants confirm, is based on the symbolic construction of boundaries and this has different interpretations about the meaning of communitas [29]. The participants thus emphasize the binding nature of communitas. The feature of symbols is that they have no objective content or inherent meaning. Their form may persist, and the meaning of that form may change. This gives symbolic forms a versatility that allows them to adapt to changing circumstances.

"Surely the community contributes to this kind of celebration and when you are in the community then you feel somehow more spurred and enthralled and that it creates a greater sense of holiness ... the religious experience is best and most intensively experienced in the community. Collective memory is important because it is in the community. Collective stands for community ... Christianity allows me freedom for something and I can decide what I want to be. And this is what the community gives me, by example and with example." (S3)

“... I do not think I would be the same person, in terms of character, mentally... so, I think that opens my horizons, the possibility of repairing behavior and any relationships. I am, for example, a person, if we can honestly speak, who would bother a lot with others because somehow I always rely on my heart ... but it gave me a message-stop, you can't, it's like some fuse that lights up and then I feel I should hold my horses. And this, for example, is the result of that religious experience." (S3)

The participants did not favor the ideology of nationalism that has always connected the idea of the political community with the primordial cultural community. According to the nationalist concept of community, the nation-best embodied in the political form of the state- exists only as an expression of a primal reality: cultural community shaped through common history, language, customs, etc. [31] (pp. 16, 17). The idea of belonging to a Christian community in Croatian society can be portrayed in the Catholic Church in Croatia within an ethnicity that has survived industrial development and once again become a basic social group [69].

\section{Reasons for Interweaving of the Religious and the National}

“... The church had to learn here for some time, because it now learned, practically, that it should not privilege any political option, at least publicly, in words, because none of them is really a church option. Each of these is one political option with which the Church shows some closeness, but also some distance. That, at the level of practice, does not always work that way, and I think one should be pretty clear here that it is one thing to say publicly that the Church hesitates from privileging someone and telling people who they should vote for and they should vote conscientiously from gestures that people recognize as I privilege one political option as opposed to another..." (S2)

"I do not approve of national symbols in religion... God is the God of all people, so that we should stop here.... The church is invited and obliged to speak on border issues concerning human. If politics involved in it, it was not the fault of Church... I believe that the Church should never be politically eligible and I do not think it is politically eligible." (S3)

Participants confirm that the Church, as an institution in the value market of welfare societies, has no longer a legitimate monopoly and ceases to be an equal partner in rivalry with the state, as it descends among other participants in the social game of expressing its 
own particularities [70] (p. 456). For this reason, the Christian community in (post) modernity, according to participants, seeks those forms of thought and action that can link the particular with the general, contributing to intercultural and interreligious communication, mutual understanding and the creation of universal social consensus.

The followers of the tradition of symbolic interaction insist on the view that the constitution of social life is essentially a symbolic constitution. The constitution of society is a "comprehensive frame of reference in society known to its members as social reality" [41] (p. 4). In order to understand the action of social participants, it is necessary to start by stating that social action is formed or constructed by interpreting the situation [41] (p. 4). Namely, Afrić points out that a person, as an active unit, must necessarily identify the things she/he takes into account. Identifying things that go into one action, and evaluating the relationship between those things and the action itself is what William Thomas calls "defining the situation". Thomas argues that if one defines a situation as real, it will be real in its consequences, that is, it is far more important to know what people think is happening than "what is actually happening". In this sense, the meaning of the term "defining a situation" should not be understood simply as a description of a situation, but as an active process of constructing a reality in which people are the authors of their own experiences [41] (p. 4).

\section{Conclusions}

This paper is a kind of contribution to advocating the crucial importance of sociological interaction in exploring the area of the popular religion as one of the traditional forms of religiosity. A kind of attempt to recognize symbolic interactions in folk or popular religiosity, and religiosity, which is in its simplest form communitas before the society in which individuals participate in traditional feasts, old rituals and pilgrimages. The need to understand popular religion in itself (understanding popular religion as a meta-social phenomenon that cannot be reduced or explained only by social relations) requires a qualitative method by itself. This approach seeks to answer the fundamental questions about the origin, meaning, and function of popular religion (directly related to phenomenological and interactionist approach). Participants perceive popular religion actually as a religion of the people in its simplicity, naivety, ignorance, and honesty; without provision and revision. In this respect, popular religion is more flexible than one might think at first glance. Popular religion is communitas, a term that emphasizes a particular social connection that exists in all types of society and which cannot be reduced to a community in terms of fixed and spatially specific grouping. The experiential relationship emphasizes the aspect of community relationship by which symbols and their occurrence in rituals signify community in relation to other communities. Aspiration of the modern human to seek the sacred through the contents and meanings of popular religiosity encourages the individual in the community to revitalize the religious question and fundamental religious truths and values. Hence, symbolic interaction of the sacred can be seen as an expression of the contemporary values and conditions that are central to today's experience of life-the symbolic liminal experience of communicative belonging in an insecure world. In this sense, popular religion originates from society, but religiosity remains permanently in humans.

Author Contributions: Conceptualization, V.K., K.M., G.K.; methodology, V.K., K.M.; validation, V.K., K.M., G.K.; formal analysis, K.M.; investigation, V.K., K.M.; resources, V.K.; data curation, K.M.; writing—original draft preparation, V.K., K.M., G.K.; writing—review and editing, V.K., K.M., G.K. All authors have read and agreed to the published version of the manuscript.

Funding: This research received no external funding.

Institutional Review Board Statement: The protocol was approved by the Ethics Committee of Faculty of Humanities and Social Sciences, University of Split (Class: 003-08/21-03/0002 Ref.No.: 2181-190-02-7/2-21-0001). 
Informed Consent Statement: Anonymity and privacy of participants in any part of the paper is not compromised and they cannot be identified. We consider that the proof of the participants' consent to participate and to give material for analysis is the consent to the interview itself, especially because these are in-depth, multi-hour interviews which were done for the purpose of conducting the research which was clearly communicated before each interview. The research participants were given the opportunity to withdraw at any time, which was not the case.

Data Availability Statement: During the research we did not find research findings that precisely dealt with symbolic interactions in popular religion.

Conflicts of Interest: The authors declare no conflict of interest.

Sample Availability: Samples of the compounds are available from the authors.

\section{References}

1. Noth, W. Handbook of Semiotics; Indiana University Press: Bloomington, IN, USA, 1990.

2. Jung, C.G. Approaching the Unconscious. In Man and His Symbols; Aldus Books Limited: London, UK, 1964.

3. Vernon, G.M. Sociology of Religion; Mc Graw-Hill Book Company, Inc.: New York, NY, USA, 1962.

4. Kertzer, D.I. Ritual, Politics, and Power; Yale University Press: New Haven Conn, CT, USA, 1988.

5. Burke, P.J.; Stets, J.E. Identity Theory; Oxford University Press: Oxford, UK, 2009.

6. $\quad$ Barthes, R. Mythologies; Editions du Seuil: Paris, France, 1957.

7. Collins, R. Interaction Ritual Chains; Princeton University Press: Princeton, NJ, USA; Oxford, UK, 2005.

8. Rossi, I. From the Sociology of Symbols to the Sociology of Signs: Toward a Dialectical Sociology; Columbia University Press: New York, NY, USA, 1983.

9. Trako Poljak, T. Hrvatski Simbolički Identitet: Značenje Nacionalnih Simbola iz Perspektive Hrvatskih građAna; TIM Press: Zagreb, Croatia, 2016.

10. Platon. Ijon, Gozba, Fedar; Kultura: Beograd, Serbia, 1970.

11. Morris, C.W. Foundations of the Theory of Signs. In International Encyclopedia of Unified Science; The University of Chicago Press: Chicago, IL, USA; London, UK, 1971; Volume 1, pp. 1-10.

12. Fink, E.L. The International Encyclopedia of Interpersonal Communication. Symbolic Interactionism; John Wiley \& Sons Inc.: New York, USA, 2016; pp. 1-13. [CrossRef]

13. Blumer, H. Symbolic Interactionism, Perspective and Method; Prentice Hall: Englewwod Cliffs, NJ, USA, 1969.

14. Liamputtong, P. Qualitative Research Methods; Oxford University Press: Oxford, UK, 2020.

15. Mead, G.H.; Dvornik, S. Um, Osoba i Društvo: Sa Stajališta Socijalnog Biheviorista; Naklada Jesenski i Turk: Zagreb, Croatia, 2003.

16. Turner, V.; Turner, E. Image and Pilgrimage in Christian Culture. Anthropological Perspectives; Columbia University Press: New York, NY, USA, 1978.

17. Cassirer, E. The Philosophy of Symbolic Forms; Routledge: London, UK, 2020.

18. Kasirer, E. Filozofija Simboličkih Oblika. Mitsko MišLJENJE; Književna zajednica Novog Sada: Novi Sad, Serbia, 1985.

19. Morinis, A. Sacred Journeys. The Anthropology of Pilgrimage; Greenwood Press: Westport, CT, USA; London, UK, 1992.

20. Jukić, J. Povratak Svetoga. Rasprava o pučKoj Religiji; Crkva u Svijetu: Split, Croatia, 1988.

21. Berryman, E. Medjugorje's Living Icons: Making Spirit Matter (for Sociology). Soc. Compass 2001, 48, 593-610. [CrossRef]

22. Plannet, R. Le Catholicisme Populaire; Editions du Centurion: Paris, France, 1974.

23. Mardešić, Ž. Rascjep u Svetome; Kršćanska Sadašnjost: Zagreb, Croatia, 2007.

24. Malenica, K.; Kovačević, V.; Kardum, G. Impact of Religious Self-Identification and Church Attendance on Social Distance toward Muslims. Religions 2019, 10, 276. [CrossRef]

25. Delanty, G. Community; Routledge: London, UK, 2018.

26. Jukić, J. Ogled o pučkoj religiji. Vjesn. đAkovačKe Srijem. Biskup. 1989, 42, 83-86.

27. Kovačević, V. Kršćanski Ethos. Život Između Boga i čovjeka u činu—Znaku; Diplomski Rad: Zagreb, Croatia, 2002.

28. Juroš, T.V. Kako nastaju kolektivna sjećanja: promišljanja o interakcionističkom modelu kolektivnih sjećanja. Rev. Sociol. 2010, 40, 79-101.

29. Cohen, A.P. The Symbolic Construction of Community; Routledge: London, UK; New York, NY, USA, 1985.

30. Turner, V. The Ritual Process. Structure and Anti-Structure; Aldine de Gruyter: New York, NY, USA, 1997.

31. Zeman, M.G.; Zeman Z. Uvod u Sociologiju (Održivih) Zajednica; Institut društvenih znanosti Ivo Pilar: Zagreb, Croatia, 2010.

32. Wunenburger, J.J. Le Sacré; Puf: Paris, France, 2010.

33. Charon, J. Symbolic Interaction: An Introduction, an Interpretation an Intergraton, 2nd ed.; Prentice-Hall: Englewood Cliffs, NJ, USA, 1985.

34. Haralambos, M.; Holborn, M. Sociologija. Teme i Perspektive; Golden Marketing: Zagreb, Croatia, $2002 ;$ p. 519.

35. Zrinščak, S. Sociologija Religije: Hrvatsko Iskustvo; Pravni Fakultet: Zagreb, Croatia, 1999; p. 123.

36. Thompson, J.B. Ideology and Modern Culture: Critical Social Theory in the Era of Mass Communication; John Wiley and Sons: Hoboken, NJ, USA, 2013. 
37. Kovačević, V.; Bilić, L.; Spetič, M. Popular Religion in the Life of Students in Split. Int. J. Interdiscip. Cult. Stud. 2016, 11, 39-54. [CrossRef]

38. Des Chene, M. Symbolic Anthropology. In Encyclopedia of Cultural Anthropology; Levinson, D., Ember, M., Eds.; Henry Holt: New York, NY, USA, 1996.

39. Wellmer, A. Zur Dialektik von Moderne und Postmoderne; Suhrkamp: Frankfurt am Main, Germany, 1985.

40. Jukić, J. Lica i Maske Svetoga. Ogledi iz drušTvene Religiologije; Kršćanska sadašnjost: Zagreb, Croatia, 1997; p. 296.

41. Afrić, V. Simbolički interakcionizam. Rev. Sociol. 1988, 19, 1-13.

42. Kovačević, V. Ideja zajednice u sociološkoj misli i kršćanska zajednica. Nova Prisut. 2019, 17, 251-265. [CrossRef]

43. Tong, A.; Sainsbury, P.; Craig, J. Consolidated criteria for reporting qualitative research (COREQ): A 32-item checklist for interviews and focus groups. Int. J. Qual. Health Care 2007, 19, 349-357. [CrossRef]

44. OBrien, B.C.; Harris, I.B.; Beckman, T.J.; Reed, D.A.; Cook, D.A. Standards for reporting qualitative research: A synthesis of recommendations. Acad. Med. 2014, 89, 1245-1251. [CrossRef]

45. Halmi, A.; Crnoja, J. Kvalitativna istraživanja u društvenim znanostima i humanoj ekologiji. Soc. Ekol. 2003, 12, 195-210.

46. De Jong, G.F.; Faulkner, J.E.; Warland, R.H. Dimensions of religiosity reconsidered; Evidence from a cross-cultural study. Soc. Forces 1976, 54, 866-889. [CrossRef]

47. Glock, C.Y. On the study of religious commitment. Relig. Educ. 1962, 98-110. [CrossRef]

48. Rock, P. Participant observation. In The Making of Symbolic Interactionism; Palgrave Macmillan: London, UK, 1979.

49. Ritzer, G. Suvremena Sociologijska Teorija; Nakladni zavod Globus: Zagreb, Croatia, 1997.

50. Ferguson, H. Phenomenological Sociology. Ensight and Eperience in Modern Society; Sage Publications: Nottingham, UK, 2006.

51. Garfinkel, H. Studies in Ethnomethodology; Polity: Los Angeles, CA, USA, 2018.

52. Pace, E. Perché le Religioni Scendono in Guerra? Roma-Bari: Laterza, Italy, 2004.

53. Kale, E. The Cultural Identity of Croatia. Croat. Political Sci. Rev. 1992, 1, 33-52.

54. Simmel, G. Soziologie: Untersuchungen über die Formen der Vergesellschaftung; BoD-Books on Demand, Erscheinungsort: VillingenSchwenningen, Germany, 2015.

55. Nesti, A. Problemi e Tendenze Nella Religione Popolare Come Fenomeno Delle Classi Subalterne; Studi e ricerche di Sociologia, Tellini: Pistoia, Italy, 1973.

56. Schmitt, J.C. «Religion populaire» et culture folklorique. Ann. Hist. Sci. Soc. 1976, 31, 941-953. [CrossRef]

57. Rosa, G.D. Vescovi, Popolo e Magia nel Sud; Guida: Napoli, Italy, 1971.

58. Jukić, J. Budućnost Religije. Sveto u Vremenu Svjetovnosti; Matica hrvatska: Split, Croatia, 1991; p. 41.

59. Morris, E. Our Own Devices: National Symbols and Political Conflict in Twentieth-Century Ireland; Irish Academic Press: Dublin, Ireland, 2005.

60. Victor, T. Betwixt and Between: The Liminal Period in Rites de Passage. The Forest of Symbols. Aspects of Ndembu Ritual; Cornell University Press: London, UK, 1967.

61. Kant, I. Critique of the Power of Judgment; Cambridge University Press: Cambridge, UK, 2000.

62. Biti, V. Pojmovnik Suvremene knjižEvne Teorije; Matica Hrvatska: Zagreb, Croatia, 1997.

63. Cassirer, E. Ogled o čovjeku; Naprijed: Zagreb, Croatia, 1978.

64. Miller, D. The Meaning of Role-Taking. Symb. Interact. 1981, 4, 167-175. [CrossRef]

65. Marić, S. Arhajski čovek i mit. In Elijade, M. Sveto i Profano; Književna Zajednica Novog Sada: Novi Sad, Serbia, 1986.

66. Strayker, S. Symbolic interactionism as an approach to family relations. In Symbolic Interaction; Manis, J.G., Meltzer, B.N., Eds.; Allyn \& Bacon: Boston, MA, USA, 1978; Volume 1, pp. 323-332.

67. Šimić, J. U potrazi za definicijom pučke pobožnosti. EtnološKa Trib. 1994, 17, 43-52.

68. Schillebeeckx, E.C.F.A. Christus, Sacrament van de Godsontmoeting; Nelissen: Bilthoven, The Netherlands, 1960.

69. Bell, D. The Cultural Contradictions of Capitalism; Basic Books: New York, NY, USA, 1976.

70. Mardešić, Ž. Crkva, liberalizam i modernitet. In Collection: Liberalizam i katolicizam u Hrvatskoj; Zaklada Friedrich Naummann. II. dio: Zagreb, Croatia, 1999. 